\title{
THE IN VITRO PRESERVATION AND POST-TRANSFUSION SURVIVAL OF STORED BLOOD ${ }^{1}$
}

\author{
By J. F. ROSS, 2 C. A. FINCH, W. C. PEACOCK, AND M. E. SAMMONS \\ (From the Evans Memorial, Massachusetts Memorial Hospitals, the Department of Medicine, \\ Boston University School of Medicine, the Department of Biochemistry, Harvard \\ Medical School, and the Department of Physics, Massachusetts \\ Institute of Technology)
}

(Received for publication February 17, 1947)

\section{INTRODUCTION}

The therapeutic value of blood transfusion is well established and experiences during World War II demonstrated the urgent need for readily available supplies of whole blood. Blood plasma and plasma "substitutes," although effective in combatting shock and in replacing plasma lost into burned and traumatized areas, cannot restore erythrocytes lost from hemorrhage or intravascular destruction (1).

Civilian and military experiences have demonstrated the practicability and value of whole blood stored or "banked" in advance of need, and immediately available for use in any emergency. In civilian practice, the blood bank has greatly facilitated the procedure of blood transfusion and has made feasible the routine use of whole blood transfusion. In military practice, banked blood is an absolute essential since it is impractical to bleed donors for transfusion under combat conditions, but it is under these very conditions that whole blood is most urgently needed.

Although stored blood is highly desirable practically and economically, to be effective, the viability of the erythrocytes must be maintained during the period of storage since the major purpose of transfusing whole blood is to supply the recipient with functional erythrocytes. Erythrocytes destroyed immediately after transfusion not only are valueless to the recipient, but the intravascular liberation of large amounts of hemoglobin from

\footnotetext{
1 The work described in this paper was done under contracts recommended by the Committee on Medical Research between the Office of Scientific Research and Development and the Massachusetts Memorial Hospitals and the Massachusetts Institute of Technology.

2 Formerly Welch Fellow in Internal Medicine, National Research Council. These investigations were carried on while under tenure of the Welch Fellowship in Internal Medicine.
}

destroyed cells actually is deleterious and dangerous to the recipient. The life span of the erythrocyte in vivo is between 100 and 120 days but after removal from the circulation the period of viability is greatly reduced. Unless special precautions are observed, blood is unsatisfactory for transfusion purposes after storage for periods as brief as $\mathbf{3}$ to $\mathbf{5}$ days (2).

Attempts to preserve the functional capacity of stored erythrocytes were first made by Rous and Turner in 1916 (3) with considerable success. Robertson, an English army surgeon, using the solution devised by Rous and Turner, made the first successful use of bank blood during the first World War (4). The solution of Rous and Turner had several serious shortcomings, however, and did not receive general use. During the ensuing 20 years various modifications of the Rous and Turner solution were made and many new types of preservative solutions were devised ( 5 to 11). None of these preservatives was entirely satisfactory, however, and little exact information was presented as to how effective each actually was in maintaining the viability of the stored cells.

Under the stimulus of World War II various English (12 to 16$)$ and Canadian $(17,18)$ workers reinvestigated the entire subject of blood preservation, and used as the criterion of effective preservation the post-transfusion survival of erythrocytes determined with the differential agglutinating techniques of Ashby (19) and of Wiener (20). These agglutinating techniques allow a qualitative comparison of the effectiveness of various preservatives, and also make possible the determination of the total duration of time that transfused cells survive in the recipient's circulation. As usually performed, however, these methods do not permit an accurate quantitative evaluation of the immediate post-transfusion erythrocyte survival; yet it is this immediate survival that is most 
important in the majority of transfusions. In general, however, the findings and conclusions of the English investigators have been similar or identical to ours which were obtained with a very different, and, we believe, more exact technique.

To determine the most effective method of preserving the viability of erythrocytes in stored blood, we have investigated 16 preservative solutions. We have judged the effectiveness of these solutions from the standpoint of the post-transfusion survival of erythrocytes stored for varying lengths of time in each solution, and we have determined the post-transfusion survival of red blood cells by the radioactively labeled erythrocyte technique previously described by Ross and Chapin (2). In an attempt to determine which factors in the preservative medium promoted cell survival, extensive studies of the changes in physical and chemical properties of the stored blood were made in conjunction with the survival studies. It soon became apparent to us, as it has to others $(21,22)$, that the in vitro characteristics of stored blood are of little value in predicting the suitability of stored blood for transfusions. The really significant criterion of the value of a blood preservative is how well it maintains the viability of the stored erythrocytes, and this attribute can be judged only by studying the survival of the cells after transfusion into a recipient.

\section{PROCEDURES AND METHODS}

The radioactively labeled erythrocyte technique of evaluating the survival of erythrocytes following transfusion has been outlined in a previous paper (2). In brief, this method consists of administering orally or parenterally one of the radioactive isotopes of iron to a prospective blood donor whose hematopoietic system incorporates the radioactive iron in the hemoglobin molecules of newly formed erythrocytes. These erythrocytes are thus "labeled," since once an atom of radioactive iron is built into the hemoglobin molecule it does not exchange with the nonradioactive iron of the plasma or tissues. It remains within the erythrocyte during its lifetime and is liberated from the red cell only when the red cell is destroyed (23). Hemoglobin and erythrocytes containing this radioactive material differ in no physiological respect from unlabeled cells, but by appropriate physical techniques $(24,25)$ they can be accurately detected when present in dilutions as great as 1 in 3,000 .

When donor cells labeled with radioactive iron are transfused into compatible recipients, they rapidly mix with the recipient's cells but still can be detected quantitatively in samples of the recipient's blood. If the labeled cells are destroyed after transfusion, there is a decrease in the concentration of radioactivity in the recipient's blood, and samples taken consecutively will reveal the extent and rate of cell destruction. The effectiveness of various blood preservatives can thus be evaluated by observing their influence on the survival of transfused radioactively tagged erythrocytes.

\section{Preparation of donors of radioactively labeled erythrocytes}

In evaluating the effectiveness of preservative solutions we believe that considerable importance should be attached to procuring uniformity in the donor blood. Individual variations in the bloods of different donors may markedly influence the storage and transfusion properties of the donor's erythrocytes and give erroneous impressions of the preservative solutions under investigation. To eliminate the factor of donor-cell variation from our studies all bloods used in our experiments were procured from a single blood donor with the exception of a series of control observations when blood was obtained from a second donor. The behavior of the cells of these 2 donors was identical. Both donors were healthy young adult males with normal erythrocyte, hemoglobin, and leukocyte characteristics. The blood of donor I, on whom most of the observations were made, was Group $\mathrm{O}, \mathrm{Rh}$ factor negative. Donor II provided blood for control observations. His blood was Group $\mathrm{O}, \mathrm{Rh}$ factor positive.

The radioactive isotope of iron, $\mathrm{Fe}^{55}$, was administered intramuscularly or intravenously in an aqueous solution of iron and ammonium citrate. Donor I received 2 series of injections. In the first series a total of $4.68 \mathrm{mgm}$. of iron with an activity of $7,000,000$ counts per minute was given in 20 injections during a period of 71 days. A second series of injections was administered 8 months later when $4.36 \mathrm{mgm}$. of iron with an activity of $6,610,000$ counts per minute were given over a period of 74 days. The activity is expressed as the absolute number of counts determined with a beryllium window Geiger-Müller counter (25). The radioactive iron was rapidly incorporated in the newly formed hemoglobin and erythrocytes of the donors. Although the rate of incorporation into hemoglobin and the percentage utilization of the injected radioactive iron are considered in a separate publication, we may point out that approximately 60 per cent of a given dose of injected radioactive iron appeared in the circulating erythrocytes of the donors and that maximum utilization of a single dose was complete in approximately 20 days. The maximum specific radioactivity produced in the donor's blood amounted to 4,180 counts per minute per ml. of erythrocytes, 12,550 counts per minute per gram of hemoglobin, or 3,760 counts per minute per $\mathrm{mgm}$. of hemoglobin iron.

Since the labeling radioactive iron first becomes available to the donor for hemoglobin synthesis at the time of the first injection of the isotope, the maximum age of the donor erythrocytes is determined by the interval of time elapsing between the first injection of radioactive 
iron and the times that the donor is venesected and the blood transfused. Thus, it is possible to state definitely that the labeled cells of a given transfusion have a maximum age of 7 days, 30 days, 100 days, etc. As previously described (2), radioactive iron liberated from destroyed radioactively labeled erythrocytes is rapidly reutilized by the body and incorporated into newly formed hemoglobin and erythrocytes. Therefore, 4 to 6 months after the first injections of radioactive iron the labeled cells are representative of the mixed age population of the whole cell mass. These considerations are important in evaluating the behavior of young, old, and mixed age cells during storage and after transfusion.

With the exception of the previously reported (2) observations on blood stored in tri-sodium citrate solutions the donor erythrocytes used for these studies varied in possible maximum age from 80 days to 120 days. The majority of observations were made on bloods in which the radioactive labeled cells were of all ages and were representative of the age distribution of the entire erythrocyte population.

\section{Technique of collection and storage of radioactively labeled donor blood}

After a fasting period of at least 12 hours the donors were bled from an antecubital vein through a closed system into the preservative solution under investigation. Except when noted to the contrary, 400 to $500 \mathrm{ml}$. of blood were drawn into the preservative solution contained in a $600-\mathrm{ml}$. pyrex Fenwal transfusion bottle, both solution and container previously having been chilled to $4^{\circ} \mathrm{C}$. The blood was stored immediately in the dark in a stationary mechanical refrigerator thermostatically regulated at $4^{\circ}$ to $6^{\circ} \mathrm{C}$. until aliquots were removed for transfusion.

\section{Recipients of transfusions}

All recipients were normal healthy adult male or female medical students, internes, or hospital technicians. The use of normal individuals excluded the uncontrollable factor of effect of disease processes in the recipient on the post-transfusion survival of erythrocytes. All donors and all recipients used in these studies were of blood group $O$. Most of the studies were performed with $\mathrm{Rh}$ negative ( $\mathrm{rh}$, rh or cde, cde) blood. In experiments in which $\mathrm{Rh}$ positive blood was employed, only $\mathrm{Rh}$ positive recipients were used. Careful cross-matching with the Landsteiner test tube technique verified complete compatibility between donor and recipient bloods in all cases.

We believe that the use of donor blood of the same blood group as that of the recipient is important in these studies, since it is now well established that the iso-agglutinins contained in transfused blood may destroy the recipient's own erythrocytes (26). If this should occur following a transfusion of radioactively labeled blood the specific radioactivity of the recipient's erythrocytes would be increased and a false impression of the post-transfusion survival would be obtained.

\section{Techniques of transfusion and sampling of recipi- ents}

All transfusions were given early in the morning while the recipient was in a fasting state. The recipient remained in bed during the course of the injection of the blood and for 1 hour thereafter, and then resumed full activity.

Aliquots of radioactively labeled blood for transfusion and for hematologic, chemical, and radioactive studies were removed by aspiration from the storage flasks after the cells and plasma had been gently and thoroughly mixed by rotation. The storage flask was then returned to the refrigerator. Immediately after removal from the storage flask a known amount, usually $100 \mathrm{ml}$., of the chilled blood was injected into the recipient through a No. 18 needle from a calibrated $100-\mathrm{ml}$. syringe. Two to 4 minutes were required to make the injection. A known amount of the dye T-1824 was then immediately injected through the same needle into the vein of the recipient for purposes of plasma volume determination.

Samples of blood for hematologic study and for radioactivity and $\mathrm{T}-1824$ concentration determinations were subsequently removed through a No. 18 needle in the opposite arm. A portion of the sample was placed in the mixed oxalate of Heller and Paul (27) for hematologic study, and the remainder of the sample was placed in a calibrated conical centrifuge tube and allowed to clot. The serum from the clotted blood was used for spectroscopic study and for determination of T-1824, hemochromogen, and bilirubin concentrations. The red blood cells from a known volume of oxalated and clotted blood were digested for radioactivity determinations as subsequently described. The exact volume of red blood cells and the amount of hemoglobin in each sample were calculated from the volume of blood and the hematocrit and hemoglobin values determined on an aliquot of this blood.

Ninety transfusions of blood were given in this fashion. There were no reactions of any sort in 88 of the subjects. Two subjects experienced a mild febrile reaction which was proved to be caused by the lot of $\mathrm{T}-1824$ dye solution used for the blood volume determination in these 2 subjects.

\section{Radioactivity determinations}

The specific radioactivity of the donor's and recipient's whole blood, erythrocytes, hemoglobin, and hemoglobin iron was determined with techniques similar to those described by one of us in previous papers $(2,24)$, with some modifications (25). In these experiments we have used the radioactive isotope $\mathrm{Fe}^{55}$ (half life approximately 5 years) instead of the radioactive isotope $\mathrm{Fe}^{59}$ (half life 47 days). The longer half life of $\mathrm{Fe}^{55}$ makes this isotope much more satisfactory than $\mathrm{Fe}^{59}$ for long-term cell tracing experiments. The radiations from $\mathrm{Fe}^{55}$ are low energy $x$-rays and have necessitated the use of a beryllium window counting tube (25) instead of the thin mica window tube previously used. The preparation of the samples of blood for determination of radioactive con- 
tent by acid digestion, neutralization, and precipitation of iron is identical with those previously described (24) with the exception that the iron in the present series of experiments was precipitated as ferric hydroxide instead of ferrous sulfide.

To eliminate variation in self-absorption the iron content of each sample was determined by multiplying the grams of hemoglobin in the sample by 0.00334 (that fraction of hemoglobin which is iron) and then enough nonradioactive iron was added to the sample to make its total iron content $10 \mathrm{mgm}$.

The iron was electrolytically deposited in a uniform, thin layer on copper discs as previously described $(24,25)$, but the plating process was carried out from a ferric rather than a ferrous solution. This required a longer period of electroplating than was the case when a ferrous solution was employed but was satisfactory for quantitative removal of the iron.

An aliquot of the donor blood which had been injected into each subject was assayed for radioactivity with the radioactivity determination of each sample of the recipient's blood, thus eliminating the necessity of making corrections for the decay of the radioactive iron, counting tube variations, etc.

\section{Determination of plasma, blood and erythrocyte volumes}

The determination of the post-transfusion survival of erythrocytes by any method is no more accurate than the accuracy with which the total circulating erythrocyte volume of the recipient is determined. This is true not only of the radioactively tagged cell method but also of the Ashby (19) and Wiener (20) methods of differential agglutination. The critical significance of the total erythrocyte volume will be evident from consideration of the following formula for calculating the post-transfusion survival of radioactively labeled red blood cells.

Per cent of transfused cells surviving in the recipient's
circulation

$\begin{gathered}\text { Radioactivity per } \\ \text { ml. of recipient's } \\ \text { cells }\end{gathered}$
Total radioactivity of transfused blood

Although the radioactivity concentrations of the recipient's and donor's bloods can be determined with considerable accuracy, the method of determination and interpretation of the recipient's red blood cell volume is the subject of considerable difference of opinion. A discussion of the'latter problem is beyond the scope of this paper, but it seems worthwhile to point out that the neglect of the significance of the cell volume, the assumption that it represents a constant per cent of the body weight or surface area, or its estimation purely on the basis of the plasma volume and the uncorrected venous hematocrit will give grossly erroneous values for the survival of transfused cells. In the differential agglutinating technique of Ashby or Wiener, calculations of survival are based on the assumptions that all of the transfused cells are surviving at the conclusion of the transfusion and that the number of non-agglutinated cells present in the recipient's blood at the conclusion of the transfusion represent 100 per cent survival of the transfused cells. This assumption is not valid, since our data indicate that many transfused erythrocytes are removed from the recipient's circulation very rapidly (actually during the course of the transfusion). This is particularly true when bloods with poor survival characteristics are transfused. The poorer the post-transfusion survival of stored blood the more rapidly the non-viable cells are removed from the circulation. Because of this fact most of the studies performed with modifications of the Ashby technique have indicated erroneously high post-transfusion survival.

Calculation of the cell volume from the plasma volume and venous hematocrit repeatedly has been shown to give values 15 to 30 per cent too high, unless correction is made for the error of the hematocrit as determined by centrifugation and for the unequal distribution of plasma and cells throughout the vascular system (28 to 31 ). Unless allowance is made for these errors, the calculated survival of labeled erythrocytes after transfusion will be 15 to 30 per cent too high.

Realizing that determinations of post-transfusion erythrocyte survival and evaluation of preservative fluids and techniques were so critically affected by the red blood cell volume we have determined this volume in an identical fashion in each recipient and have determined it with a technique which we believe represents a conservative factor in evaluating the post-transfusion erythrocyte survival. Although our method may represent too small a cell volume and, therefore, a low value for post-transfusion survival, it certainly does not give too high a cell volume or indicate too high a post-transfusion survival.

The recipient's red blood cell volume was determined as follows:

1. The plasma volume was determined with the dye T-1824 according to the method of Gibson and Evans (32), samples being taken at $15,25,30,35$, and 60 minutes, and the dye concentrations being determined on serum in the micro unit of the Evelyn colorimeter.

The $\mathrm{L}$ values obtained at 620 millimicrons were corrected with a reading at 540 millimicrons to correct for the effect of serum hemoglobin (which was present in the serum following transfusion of blood with poor survival characteristics). The $\mathrm{L}$ values were also corrected for fluctuation in plasma protein concentration $(33,34)$. The disappearance curve was extrapolated to the time of injection.

2. The blood volume and cell volume were calculated from the following formula, employing the corrected hematocrit value previously described (28):

$$
\begin{aligned}
& \text { Blood volume }=\frac{\text { plasma volume }}{1-(\text { hematocrit } \times 0.92)} \\
& \text { Cell volume }=\text { blood volume }- \text { plasma volume. }
\end{aligned}
$$


3. The cell volume so determined was corrected to compensate for the error introduced by unequal distribution of erythrocytes and plasma throughout the vascular system (29).

Corrected cell volume $=$ cell volume $\times 0.85$.

The cell volumes of normal human subjects determined in this fashion compare very closely with the cell volume determined in the same subjects with the use of radioactive tagged cells (31).

We again wish to emphasize the fact that the use of the cell volume determined in this fashion provides a conservative estimate of post-transfusion erythrocyte survival and allows an accurate comparison of various preservative fluids.

\section{Calculation of post-transfusion survival}

The radioactivity present in the circulating red blood cell mass of the recipient was determined at various intervals following the transfusion by applying the formula:

Per cent of transfused radioactivity present in the recipient's
circulation

$\begin{gathered}\text { Radioactivity per } \\ \text { ml. of recipient's } \\ \text { red blood cells }\end{gathered} \times \begin{gathered}\text { Recipient's red } \\ \text { blood cell } \\ \text { volume }\end{gathered} \times 100$

Total radioactivity of the transfused blood

The specific radioactivity of the recipient's cells and thus the percent of transfused radioactivity present in the recipient's circulation decreased following the transfusion, the lowest values being reached at the end of ap- proximately 24 or 48 hours. Subsequently, the concentration of radioactivity progressively increased (Figures 1 and 2). We have interpreted the decrease in radioactivity as indicating the removal of the non-viable transfused erythrocytes from the recipient's circulation. The rate of this removal was most rapid in those bloods showing the poorest post-transfusion survival. We have interpreted the increase in radioactive iron in the recipient's circulation as indicating the reutilization of the radioactive iron liberated from the destroyed transfused erythrocytes for the formation of new erythrocytes by the recipient. Support is given to this interpretation by observations of similar buildup curves following infusion of solutions of hemoglobin labeled with radioactive iron (35).

During the first 24 hours following the transfusion the amount of radioactive iron incorporated in newly formed recipient's erythrocytes is too small to contribute significantly to the total radioactivity in the recipient's circulation. Therefore, during this period all of the radioactivity in the recipient's blood can be attributed to the presence of surviving labeled donor red blood cells and indicates post-transfusion survival. After 24 hours, the reutilization of radioactive iron and its incorporation in the recipient's own erythrocytes may occur more rapidly than the removal of the transfused labeled cells and may be great enough to indicate a falsely high post-transfusion survival.

Because of these considerations the minimum specific radioactivity of the recipient's erythrocytes, which usually is reached 24 hours after transfusion, has been adopted as indicating the minimum post-transfusion survival of the labeled donor erythrocytes.

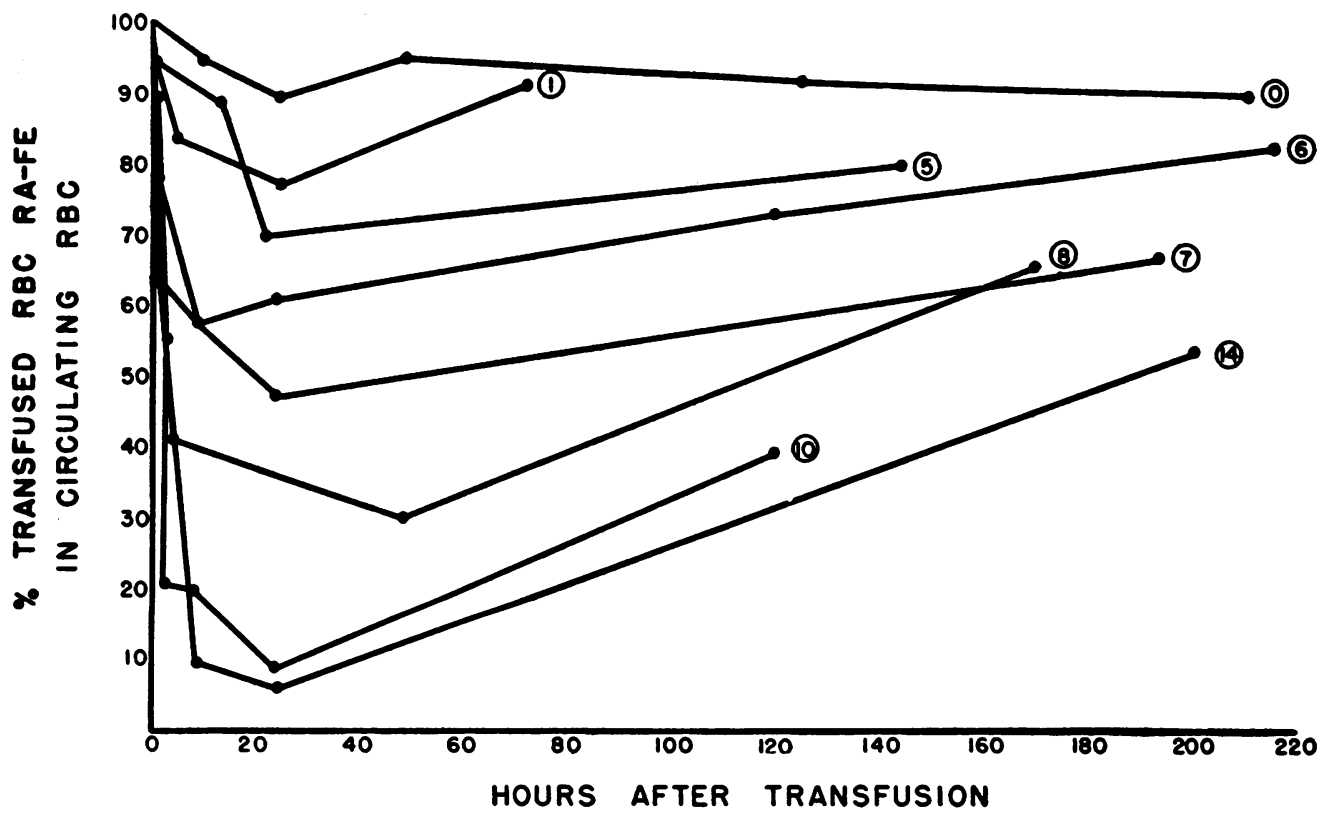

Fig. 1. The Effect of Storage at $4^{\circ} \mathrm{C}$. on the Post-transfusion Survival of Erythrocytes of Whole Blood Stored in Trisodium Citrate (solution No. 1)

The circled figures indicate the number of days the blood was stored prior to transfusion. 


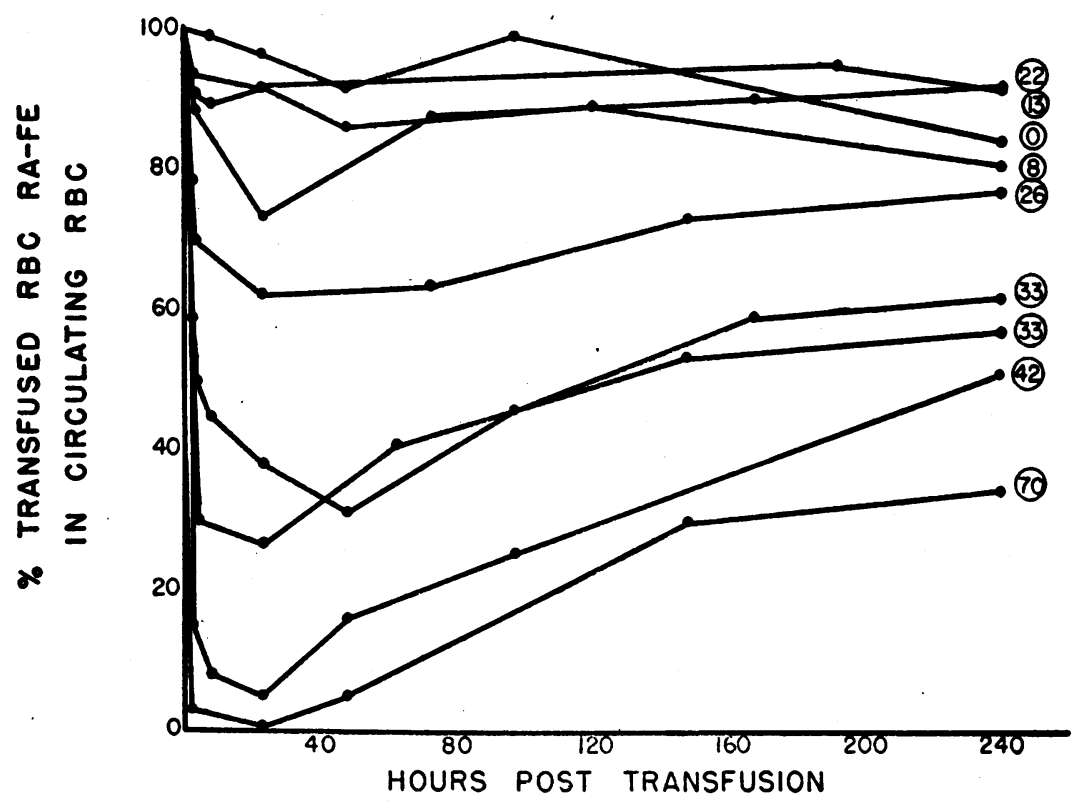

Fig. 2. The Effect of Storage at $4^{\circ} \mathrm{C}$. on the Post-transfusion Survival of Erythrocytes of Whole Blood Stored in Denstedt's Solution (soluTION No. 2)

The circled figures indicate the number of days the blood was stored prior to transfusion.

This minimum survival has been used as the criterion for evaluating the effectiveness of the blood preservative under consideration.

\section{Preservative fluids studied}

All solutions (except the corn syrup and Alsever's solutions which were obtained commercially) were prepared with pyrogen-free, freshly distilled water and reagent chemicals. All glassware and storage bottles (except the Baxter bottles containing Alsever's solution) were pyrex glass. With the exception of a few experiments that were carried out at room temperature, all bloods were drawn into containers and solutions which previously had been chilled to $4^{\circ} \mathrm{C}$. and were immedately stored at $4^{\circ}$ to $6^{\circ} \mathrm{C}$.

The fluids studied may be grouped into those used for the preservation of whole blood and those used for the preservation of erythrocytes separated from blood plasma. A description of the constitution, the methods of preparation, and use of these fluids follows.

\section{A. PRESERVATIVE FLUIDS FOR WHOLE BLOOD}

\section{Solution No. 1: Trisodium citrate}

Trisodium citrate (2.5 per cent)

$\mathrm{pH}$ of solution

Whole blood

$\mathrm{pH}$ citrate blood mixture

$50 \mathrm{ml}$.

Nineteen transfusions were given of blood stored in this solution 0 to 14 days.
Solution No. 2: Denstedt's or McGill No. II solution

Isotonic sodium citrate ( 3.2 per cent) $80 \mathrm{ml}$. Isotonic dextrose (5.4 per cent) $\quad 80 \mathrm{ml}$. Isotonic phosphate buffer $\mathrm{pH} 7.4 \quad 40 \mathrm{ml}$. Whole blood $\quad 400 \mathrm{ml}$. $\mathrm{pH}$ of solution $\quad 7.4$ $\mathrm{pH}$ solution-blood mixture $\quad 7.4$

The citrate, dextrose, and buffer solutions were prepared and autoclaved separately, cooled, and mixed with aseptic precautions in sterile Fenwal bottles according to the method described by Denstedt, et al (17). Twelve transfusions were given of blood stored in this solution 0 to 70 days.

Solutions No. 3 and 4: Alsever's solutions $\mathrm{No} \mathrm{I}_{\text {and }} \mathrm{II}^{3}$ (Baxter No. I and II)

Solution No. 3-Alsever's solution No. I

Dextrose (U.S.P.) 2.05 per cent

Sodium citrate (U.S.P.) 0.80 per cent of this $-500 \mathrm{ml}$. Sodium chloride (U.S.P.) 0.42 per cent 3 solution $-500 \mathrm{ml}$. Citric acid (U.S.P.) $\quad 0.04$ per cent

Whole blood $\mathrm{pH}$ of solution $500 \mathrm{ml}$. $\mathrm{pH}$ of solution-blood mixture 6.78 7.5

3 These solutions, modifications of the one described by Alsever and Ainsle (11), were prepared and provided by the Baxter Laboratories, Incorporated, through the courtesy of Dr. N. M. Nesset. The formulae given here were provided by the Baxter Laboratories as descriptive of their constitution. 
Four transfusions of blood stored in this solution 1 to 36 days were given.

Solution No. 4: Alsever's solution No. II

Dextrose (U.S.P.) 2.05 per cent

Sodium citrate (U.S.P.) 0.80 per cent of this $-500 \mathrm{ml}$.

Sodium chloride (U.S.P.) 0.42 per cent solution $^{-500 \mathrm{ml}}$

Citric acid (U.S.P.) 0.055 per cent

Whole blood

$500 \mathrm{ml}$.

$\mathrm{pH}$ of solution

6.0

$\mathrm{pH}$ of solution-blood mixture

7.2

Four transfusions were given of blood stored in this solution 7 to 35 days.

Solution No. 5: Acid citrate-dextrose solution of Loutit and Mollison 4

$\begin{array}{lc}\text { Disodium citrate (2 per cent) } & 100 \mathrm{ml} \\ \text { Dextrose (15 per cent) } & 20 \mathrm{ml} \text {. } \\ \text { Whole blood } & 430 \mathrm{ml} \\ \text { pH of solution } & 5.0 \\ \text { pH of solution-blood mixture } & 6.8\end{array}$

This solution was prepared according to the method described by Loutit and Mollison (14). Nine transfusions of blood stored in this solution 2 to 34 days were given.

Solution No. 6: Acid citrate-dextrose solution of reduced volume

Trisodium citrate

Citric acid

Dextrose (anhydrous)

Water

$\mathrm{pH}$

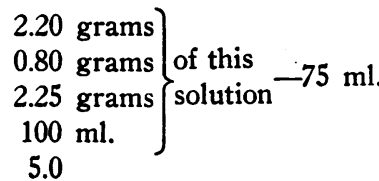

$\mathrm{pH}$ of preservative-blood

mixture

Whole blood

$500 \mathrm{ml}$

$(15 \mathrm{ml}$. of this solution used for each $100 \mathrm{ml}$. of whole blood.)

In the proportions used, this solution provided approximately 2 grams of disodium citrate per $500 \mathrm{ml}$. of blood, and an eventual 24 millimolar concentration of citrate ion in the supernatant plasma of the preservative-blood mixture. In these respects, and in the $\mathrm{pH}$ of the solution and the solution-blood mixture, solutions No. 5 and 6 were identical. The dextrose content of solution No. 6 was approximately $1 / 2$ that of solution No. 5 , however, and the volume of the diluent was 62.5 per cent of solution No. 5.

Four transfusions of blood stored in this solution 6 to 28 days were given.

4 The disodium citrate used in preparing this solution and others containing disodium citrate was kindly prepared and provided by Dr. Walter Clarke of the Eastman Kodak Company, Rochester, New York. In the event that crystalline disodium citrate should not be available a solution of disodium citrate can readily be prepared as follows :

Trisodium citrate $\left(\mathrm{Na}_{6} \mathrm{C}_{6} \mathrm{H}_{6} \mathrm{O}_{7} \cdot 2 \mathrm{H}_{2} \mathrm{O}\right)$

Citric acid $\left(\mathrm{H}_{8} \mathrm{C}_{6} \mathrm{H}_{5} \mathrm{O}_{7} \cdot \mathrm{H}_{2} \mathrm{O}\right)$

Water

$\mathrm{pH}$

1.662 grams

0.595 grams

$100 \mathrm{ml}$.

5.0
B. PRESERVATIVE FLUIDS FOR ERYTHROCYTES SEPARATED FROM THEIR PLASMA

The separated cells for solutions $7,8,9$, and 10 were prepared as follows : $450 \mathrm{ml}$. of donor blood were drawn into $50 \mathrm{ml}$. of previously chilled 2.5 per cent trisodium citrate solution of $\mathrm{pH}$ 7.5. The cells were immediately sedimented by centrifugation at 2,500 r.p.m. for 1 hour, and the plasma then removed by aspiration with aseptic precautions. For the experiments with solutions 11, and $12,400 \mathrm{ml}$. of blood were drawn into $100 \mathrm{ml}$. of 2 per cent disodium citrate solution of $\mathrm{pH}$ 5.0. Centrifugation and separation of plasma were carried out as previously described. The cell mass for solution 13 was obtained from defibrinated blood which was centrifuged and separated from its plasma as described above.

A description of the solutions and techniques used in the preservation of erythrocytes separated from their plasma follows :

Solution No. 7: Human albumin solution 5

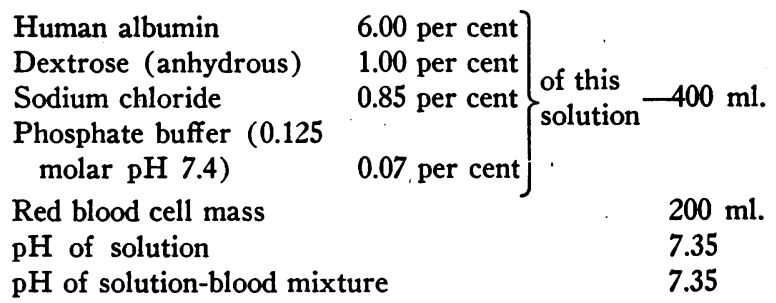

The solution was sterilized by passing it through a Seitz filter with pressure. It was chilled to $4^{\circ} \mathrm{C}$., and the packed red blood cells were pipetted into it. The cells and preservative were mixed thoroughly then stored at $4^{\circ} \mathrm{C}$.

Five transfusions of cells preserved in this fashion were given; the duration of storage varying from 10 to 46 days.

$\begin{array}{ll}\text { Solution No. 8: Corn syprup } & \\ \text { Corn syrup (10 per cent) } & 200 \mathrm{ml} \\ \text { Packed blood cells } & 200 \mathrm{ml} . \\ \text { pH of corn syrup } & 4.0 \\ \text { pH of corn syrup-blood mixture } & 6.7\end{array}$

This 10 per cent solution of sterile corn syrup was provided in ampules through the courtesy of Dr. William Thalhimer of New York City. The concentration of the corn syrup before it is diluted is stated to be (36) :

$\begin{array}{ll}\text { Dextrose } & 17.7 \text { per cent } \\ \text { Maltose } & 16.8 \text { per cent } \\ \text { Higher sugars } & 16.2 \text { per cent } \\ \text { Dextrins prosugars } & 29.6 \text { per cent } \\ \text { Moisture } & 19.7 \text { per cent }\end{array}$

The chilled corn syrup was added to the packed red blood cells, mixed by rotation, and then stored at $4^{\circ} \mathrm{C}$.

Seven transfusions of these cells were given after storage for 6 to 22 days.

5 The human albumin used in this solution was provided through the courtesy of Dr. Edwin Cohn of the Harvard Medical School. 
Solutions No. 9, 10, 11, and 12: Maltose-dextrose solutions

TABLE I

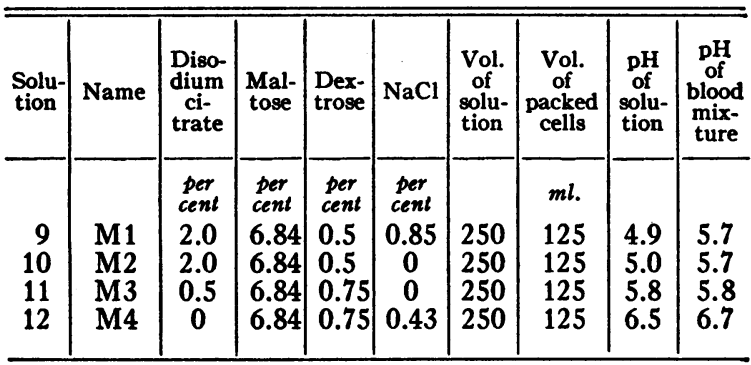

These chilled solutions were added to packed red blood cells in proportions noted. The cells for solutions No. 9 and 10 were obtained from blood drawn into trisodium citrate solution (solution No. 1). The cells for solutions No. 11 and 12 were drawn into acid citrate dextrose (solution No. 5).

Five transfusions of cells stored 7 to 14 days in these solutions were given.

\begin{tabular}{|c|c|}
\hline \multicolumn{2}{|l|}{ Solution No. 13: RPA solution ${ }^{6}$} \\
\hline \multicolumn{2}{|l|}{ grams per $l$. } \\
\hline $\mathrm{MgCl}_{2}$ & .095 \\
\hline $\mathrm{CaCl}_{2}$ & .056 \\
\hline $\mathrm{KCl}$ & .410 \\
\hline $\mathrm{NaCl}$ & 5.825 \\
\hline $\mathrm{Na}_{2} \mathrm{HPO}_{4}$ & .301 \\
\hline $\mathrm{NaHCO}_{3} *$ & 2.35 \\
\hline Glucose & 2.50 \\
\hline Difco proteose peptone & 1.50 \\
\hline Stearns A A** & 0.50 \\
\hline Glycerol & 0.25 \\
\hline Sodium acetate & 0.15 \\
\hline \multicolumn{2}{|c|}{ micrograms per $l$. } \\
\hline Adenine sulfate & 250 \\
\hline Guanine- $\mathrm{HCl}$ & 250 \\
\hline Thymine & 125 \\
\hline Xanthine & 250 \\
\hline Uracil & 250 \\
\hline Ascorbic acid & 5,000 \\
\hline Biotin & 16 \\
\hline Choline & 500 \\
\hline Cocarboxylase & 400 \\
\hline Nicotinic & 1,000 \\
\hline Nicotinamide & 1,000 \\
\hline d-Ca Pantothenate & 500 \\
\hline Pyridoxine & 500 \\
\hline Ribose & 500 \\
\hline Riboflavin & 500 \\
\hline Thiamine & 1,000 \\
\hline
\end{tabular}

* Added as $\mathrm{Na}_{2} \mathrm{CO}_{3}$ and converted to bicarbonate by passing $\mathrm{CO}_{2}$ gas through the solution.

** Fortified with glycine and histidine.

6 This solution was prepared by Dr. Eric Ball of the Harvard Medical School and was identical with the solution used by Ball and his collaborators for the in vitro cultivation of malaria parasites (37).
$\mathrm{P}$-amino benzoic acid is added to conc. 10 gamma per cent.

Medium (complete) is filtered instead of autoclaved.

The solution was added to the red blood cell mass procured from defibrinated blood in amounts sufficient to produce hematocrit values of 27,37 and 40 per cent. The cells and solution were mixed and the $\mathrm{pH}$ adjusted to 7.0 by equilibration with $\mathrm{CO}_{2}$. The mixture was stored at $4^{\circ} \mathrm{C}$.

\section{Solution No. 14: $A C D$ solution 2 per cent}

This solution is identical with solution No. 5 , but the method of handling the cell-solution mixture differs markedly from that followed with solution No. 5. Four hundred thirty $\mathrm{ml}$. of donor blood were drawn into the chilled solution. The mixture was stored at $4^{\circ} \mathrm{C}$. for 24 hours. It was then centrifuged at 2,500 r.p.m. for 1 hour and the supernatant plasma removed aseptically by aspiration. The packed cells were then stored at $4^{\circ} \mathrm{C}$. without addition of further diluent until they were transfused. The $\mathrm{pH}$ of the cell mass was 6.8. A small amount (equal to 10 per cent of the volume of cells) of 0.85 per cent sodium chloride solution at a temperature of $4^{\circ} \mathrm{C}$. was added to the cell mass at the time of transfusion.

Five such transfusions were given of cells stored 11 to 24 days.

Solution No. 15: Acid citrate-dextrose solution 5 per cent

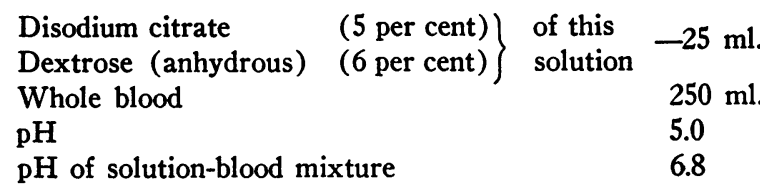

The blood was drawn into the chilled solution and stored for 24 hours at $4^{\circ} \mathrm{C}$. It was then centrifuged at 2,500 r.p.m. for 1 hour and the supernatant plasma removed aseptically by aspiration. The packed cells were stored at $4^{\circ} \mathrm{C}$. until transfused and injected without dilution.

Three transfusions were given of cells stored 7 to 22 days.

$\begin{array}{cc}\text { Solution No. 16: Acid citrate solution } 5 \text { per cent } \\ \text { Disodium citrate (5 per cent) } & 25 \mathrm{ml} \text {. } \\ \text { Whole blood } & 225 \mathrm{ml} \text {. } \\ \text { pH of solution } & 5.0 \\ \text { pH of solution-blood mixture } & 6.8\end{array}$

The blood was drawn into the chilled solution, stored at $4^{\circ} \mathrm{C}$. for 24 hours, centrifuged and the plasma removed as described above. Then $15 \mathrm{ml}$. of chilled 10 per cent dextrose solution were added to and mixed with the cell mass by rotation of the container. The mixture was stored at $4^{\circ} \mathrm{C}$. until transfused and injections were made without dilution, after storage for 9 to 22 days.

\section{Hematologic studies}

The following studies were performed on aliquots of donor blood shortly after it was drawn into the preservative solution and at intervals during the period of stor- 
age; they were also performed on aliquots of the samples removed from the recipients before and after the transfusion:

1. Erythrocyte and leukocyte counts were performed in quadruplicate, using 4 pipettes and 4 counting chambers and the average of the 4 counts was used in calculations.

2. Hematocrit determinations were made with the Wintrobe hematocrit tube and with application of a relative centrifugal force of 1,800 for 1 hour.

3. Whole blood hemoglobin concentration was determined by the Evelyn oxyhemoglobin method (38) on the Evelyn photoelectric colorimeter.

4. Erythrocyte indices were calculated according to the method of Wintrobe (39).

5. The concentration of heme pigments in the plasma of the recipient and in the supernatant plasma of the donor blood was determined according to the hemochromogen method of Flink and Watson (40).

6. The plasma bilirubin concentrations of the recipient were determined according to the method of Evelyn and Malloy (41).

7. The whole blood sugar content of the donor blood was determined by the method of Folin and Malmros (42).

8. The $\mathrm{pH}$ of the donor blood was determined with the Beckman glass electrode $\mathrm{pH}$ meter.

9. The susceptibility of the donor erythrocytes to hemolysis by hypotonic saline solutions ("osmotic fragility") was determined by the method originally suggested by Dacie and Vaughan (43) as modified by Shen, Ham, and Fleming (44).

10. The morphologic characteristics of the donor erythrocytes were observed in wet unstained preparation and in dry Wright stained preparations.

11. Spectroscopic studies were performed on plasma and serum of donor and recipient bloods with the Zeiss hand spectroscope and the Hartridge reversion spectroscope.

\section{OBSERVATIONS}

Figures 1 and 2 illustrate the post-transfusion survival of radioactively labeled erythrocytes stored in tridosium citrate (solution No. 1) and in Denstedt's solution (solution No. 2). Following transfusion the non-viable donor cells are destroyed and removed from the recipient's circulation. The number of cells removed and the rapidity with which they are removed increase with increase in the duration of storage.

The majority of the non-viable cells are removed during the first hour or 2 following transfusion and the survival curve then continues to fall more gradually during the next 18 to 20 hours. At the end of 24 hours the minimum post-transfusion survival usually is reached. It is this minimum survival which we have used as the criterion of the effectiveness of the blood preservative, and it is this value which has been used in constructing the curves in Figure 4. After 24 hours newly formed erythrocytes containing reutilized radioactive iron may be liberated in the recipient's circulation more rapidly than the labeled donor cells are removed and consequently the concentration of radioactive iron per unit volume of red cells increases.

Trisodium citrate obviously is a very poor blood preservative (Figure 1). The erythrocytes of stored citrated blood degenerated at a rate of 7 per cent per day and after storage for 7 days only 50 per cent of the transfused cells survived 24 hours (Figures 1 and 4). If we accept as an arbitrary minimum requirement for a satisfactory transfusion the survival of 70 per cent of the transfused cells for at least 24 hours following transfusion, citrated blood can no longer be considered satisfactory for transfusion if stored for longer than 5 days.

Denstedt's solution, in marked contrast to trisodium citrate, is an excellent blood preservative (Figures 2 and 4). Blood stored in this solution for 24 days showed satisfactory post-transfusion survival, and the rate of degeneration of red cells during storage was only approximately 1.4 per cent per day. There was 1 serious drawback to Denstedt's solution, however. The necessity for separately autoclaving the citrate, dextrose, and phosphate solutions and then mixing them with sterile technique made its preparation exceedingly laborious and not very satisfactory for routine use. Since the acid citrate-dextrose solution (solution No. 5) was found to have almost identical preservative powers and was much simpler to prepare, Denstedt's solution does not justify the effort required to prepare it.

The 2 Alsever's solutions studied differed only in their citric acid content and initial $\mathrm{pH}$, and were almost identical in their preservative powers (Figure 3 ). They were not good preservative solutions, since after storage for only 7 days, less than 70 per cent of the transfused cells survived 24 hours, and the rate of degeneration of the erythrocytes during storage amounted to approximately 3 per cent per day.

Another serious disadvantage of Alsever's solution is the large volume of diluent ( $500 \mathrm{ml}$.) required for the preservation of $500 \mathrm{ml}$. of blood. The addition of this large volume of fluid serves 
no useful purpose and is actually contraindicated in many blood transfusions.

The most satisfactory blood preservatives which we studied were the acid citrate-dextrose solutions, either the solution originally described by Loutit and Mollison (14) (solution No. 5) or modifications of this fluid (solutions No. 6, 14, 15, and 16). The acid citrate-dextrose solution of Loutit and Mollison (for convenience called "ACD" throughout the remainder of this paper) was an excellent blood preservative-maintaining satisfactory transfusion properties in blood stored for as long as 23 days (Figure 4) and retarding the rate of degeneration of erythrocytes during storage to only 1.4 per cent per day. In addition to its excellence as a preservative $\mathrm{ACD}$ was extremely simple to prepare. The citrate and dextrose solutions were mixed prior to sterilization, and were autoclaved together without caramelization.

The volume of ACD $(120 \mathrm{ml}$.) was not large enough to dilute the blood to any serious degree, but it was believed by the Subcommittee on Blood Substitutes of the National Research Council that a smaller volume preservative might be desirable, since it might make more simple the preparation of desiccated plasma. Therefore, solution No. 6 was devised. Its volume was only $75 \mathrm{ml}$. but it provided the same amount of disodium citrate per unit volume of blood as solution No. 5 ; it reduced significantly the amount of dextrose. The preservative properties of this solution were indistinguishable from those of solution No. 5 (Table II).

TABLE II

Survival of erythrocytes of stored whole blood

\begin{tabular}{|c|c|c|c|c|}
\hline \multirow{2}{*}{ Preserving solution } & \multicolumn{4}{|c|}{$\begin{array}{l}\text { Per cent r.b.c. surviving in the } \\
\text { recipient's circulation } 24^{\circ} \text { after } \\
\text { transfusion of blood stored }\end{array}$} \\
\hline & $\begin{array}{c}7 \\
\text { days }\end{array}$ & $\begin{array}{c}14 \\
\text { days }\end{array}$ & $\begin{array}{c}21 \\
\text { days }\end{array}$ & $\begin{array}{c}28 \\
\text { days }\end{array}$ \\
\hline $\begin{array}{l}\text { 1. Trisodium citrate } \\
\text { 2. Denstedt's solution } \\
\text { 3. Alsever's No. I } \\
\text { 4. Alsever's No. II } \\
\text { 5. Acid citrate-dextrose } \\
\text { (Loutit and Mollison) } \\
\text { ("ACD") }\end{array}$ & $\begin{array}{l}50 \\
92 \\
67 \\
68 \\
97\end{array}$ & $\begin{array}{r}3 \\
90 \\
60 \\
60 \\
92\end{array}$ & $\begin{array}{r}0 \\
73 \\
34 \\
71\end{array}$ & $\begin{array}{l}60 \\
13 \\
60\end{array}$ \\
\hline $\begin{array}{l}\text { 6. Acid citrate-dextrose } \\
\text { reduced volume }\end{array}$ & 95 & 92 & 75 & 64 \\
\hline
\end{tabular}

Similar observations were obtained with a solution of even smaller volume $(50 \mathrm{ml}$.) (solution No. 15), which was used for preservation of erythrocytes separated from plasma. The posttransfusion survival of the separated cells taken into this solution was almost identical with that of whole blood in $120 \mathrm{ml}$. volume ACD (solution No. 5) or in the $75 \mathrm{ml}$. of modified ACD (solu-

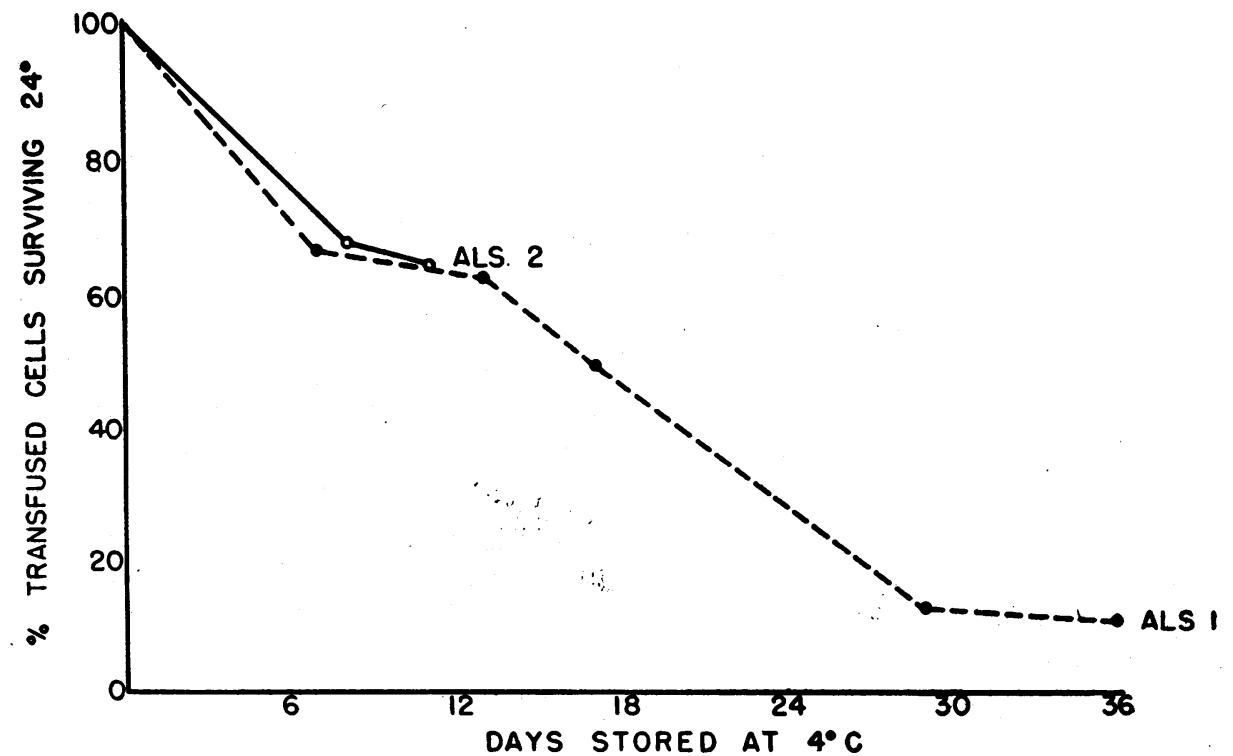

Fig. 3. Comparison of the Effect of Storage of Whole Blood in Alsever's solutions No. 1 and 2 on Post-transfusion Survival 


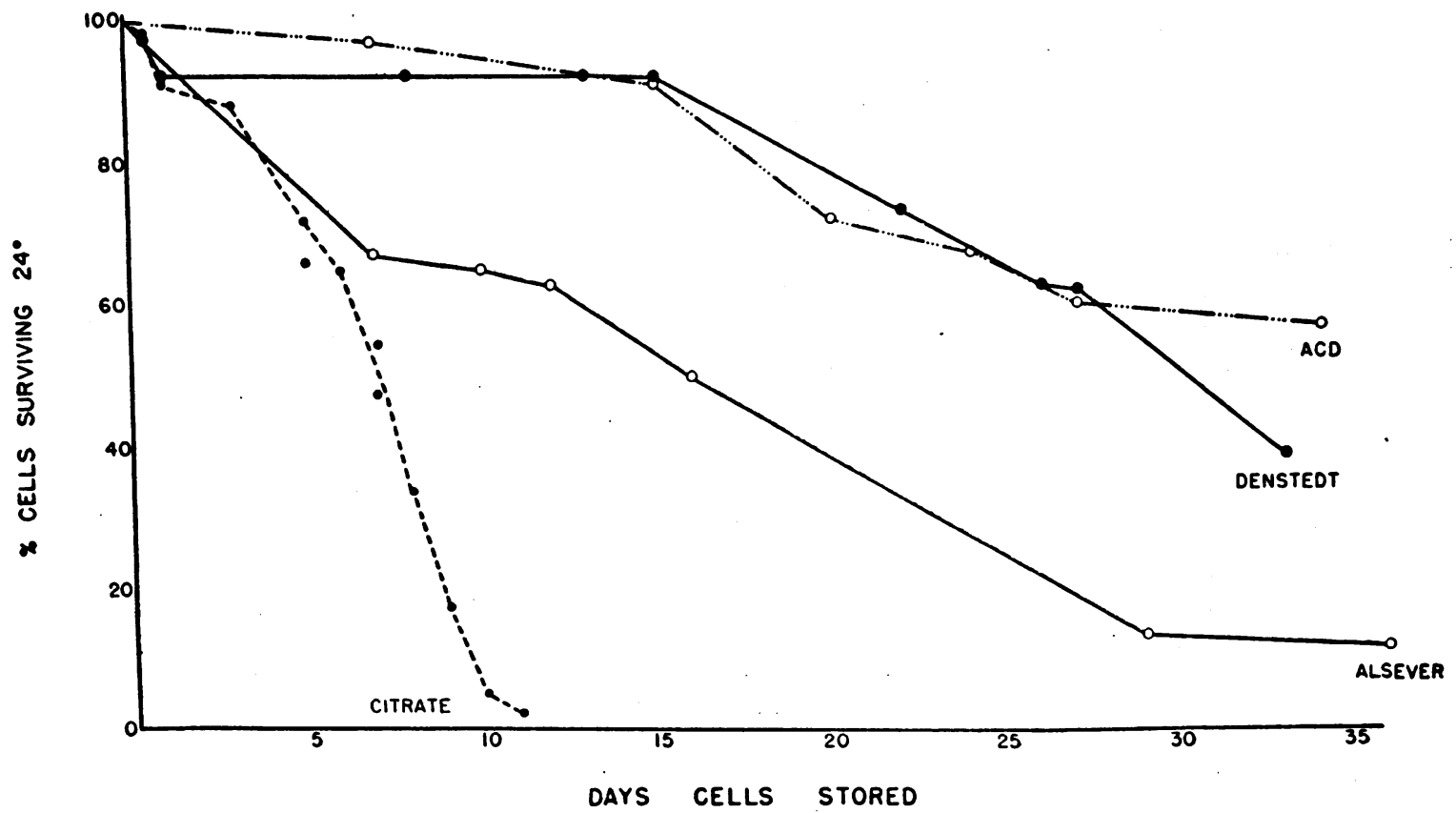

Fig. 4. Comparison of the Survival of the Erythrocytes of Whole Blood Stored at $4^{\circ}$ C. in the Acid Citrate-Dextrose Solution of loutit and Mollison (solution No. 5, “ACD”), Denstedt's Solution (solution No. 2), Alsever's (solution No. 3), and Trisodium Citrate Solution (solution No. 1)

tion No. 6). The volume of the preservative within these limits had little influence on erythrocyte preservation.

\section{Preservation of erythrocytes separated from plasma}

Since normal blood contains various hemolytic systems it was believed that erythrocytes might survive better in vitro if they could be removed from their plasma and resuspended in some other fluid. Furthermore, if some method of preserving cells separated from plasma could be devised it would salvage tremendous quantities of red blood cells which are discarded in the process of preparing blood plasma and plasma fractions. Such studies were successful in demonstrating a simple yet effective method of preserving red blood cells after separation from plasma.

The studies of Furchgott and Ponder (45) indicated that crystalbumin prevented the development of certain morphologic abnormalities in erythrocytes placed under abnormal conditions in vitro. With the hope that human albumin might exert a similar beneficial effect on stored human red cells, we resuspended erythrocytes separated from whole blood in solution No. 7. After storage for 22 days
70 per cent of the transfused cells survived 24 hours (Figure 5), which is good preservation but no better than in several far simpler and less expensive solutions.

This proved to be the case with corn syrup (solution No. 8) which was investigated at the request of the Subcommittee on Blood Substitutes. It maintained satisfactory transfusion properties in resuspended erythrocytes for only 10 days (Figure 5).

In vitro studies indicated that non-diffusible disaccharides might be effective as erythrocyte preservatives; so the maltose-dextrose solutions (solutions No. 9, 10, 11 and 12) were devised to test this possibility. Only solution No. 12 was of any value (Table III).

Ball and his collaborators (37) showed that the malarial parasite could be satisfactorily cultivated in erythrocytes suspended in the complex solution described as "RPA" (solution No. 13). It seemed possible that one of the reasons this solution supported the growth of malarial parasites was because it maintained erythrocyte viability. Therefore, we investigated the preservation of erythrocytes separated from their plasma, resuspended, and stored in this fluid. 


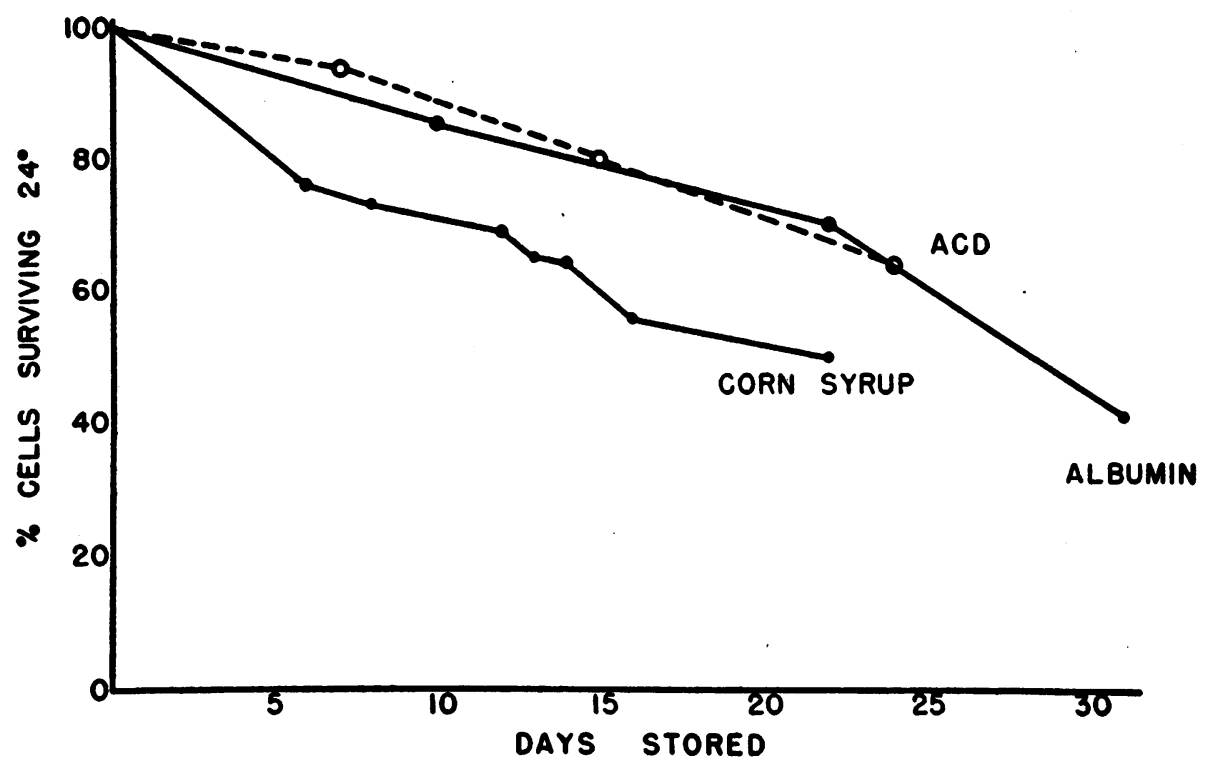

Fig. 5. Comparison of the Post-transfusion Survival of Erythrocytes Separated from Plasma

ACD represents cells separated from blood drawn into ACD and stored without addition of diluent (solution No. 14). The "albumin" and "corn syrup" cells were resuspended in solutions No. 7 and 8.

The post-transfusion survival of these cells was quite good (Table III), but, as in the case of the albumin solution, corn syrup, and maltose-dextrose solutions, it was not so good as the survival of cells stored in simpler and less expensive preservatives.

The excellence and simplicity of the ACD solutions (solutions No. 5 and 6) as whole blood preservatives and the fact that plasma was not

TABLE III

The survival of erythrocytes separated from plasma

\begin{tabular}{|c|c|c|c|}
\hline \multirow{2}{*}{ Resuspending solution or technique } & \multicolumn{3}{|c|}{$\begin{array}{l}\text { Per cent r.b.c. surviving } \\
\text { in the recipient's circu- } \\
\text { lation } 24^{\circ} \text { after trans- } \\
\text { fusion of blood stored }\end{array}$} \\
\hline & $\begin{array}{l}7 \\
\text { days }\end{array}$ & $\begin{array}{c}14 \\
\text { days }\end{array}$ & $\begin{array}{c}21 \\
\text { days }\end{array}$ \\
\hline $\begin{array}{l}\text { 7. Human albumin } \\
\text { 8. Corn syrup } \\
\text { 9. Maltose No. M1 } \\
\text { 10. Maltose No. M2 } \\
\text { 11. Maltose No. M3 } \\
\text { 12. Maltose No. M4 } \\
\text { 13. RPA solution } \\
\text { 14. ACD (2 per cent solution) } \\
\text { packed cells not resuspended } \\
\text { 15. ACD (5 per cent solution) } \\
\text { packed cells not resuspended } \\
\text { 16. AC (5 per cent solution) + dex- } \\
\text { trose added to packed cells } \\
\text { after } 24^{\circ}\end{array}$ & $\begin{array}{r}90 \\
74 \\
43 \\
0 \\
\\
81 \\
90 \\
\\
94 \\
92\end{array}$ & $\begin{array}{l}80 \\
64 \\
25 \\
20 \\
72 \\
80 \\
80 \\
78 \\
90\end{array}$ & $\begin{array}{l}63 \\
70\end{array}$ \\
\hline
\end{tabular}

essential to the preservation of erythrocytes (solutions No. 7, 8 and 12) suggested that red blood cells might survive if they were separated from blood drawn into ACD and stored without resuspension (solution No. 14). The survival of cells preserved in this fashion was excellent (Figure 5). A smaller volume ACD (solution No. 15) proved just as effective as solution No. 14 (Figure 6).

In the recovery of plasma it may be desirable in some instances not to add dextrose directly to the preservative solution until the plasma has been removed. To investigate the possibility of preserving the erythrocytes of such blood we carried out the procedure outlined in solution No. 16. Blood was drawn into 5 per cent disodium citrate solution, the plasma was removed the next day, and dextrose solution was added to the cell mass. As summarized in Table III, the survival of these erythrocytes was as good, if not slightly better than the survival of cells drawn directly into ACD.

\section{Influence of storage temperature on post-transfu- sion erythrocyte survival}

Although Rous and Turner (3) in their original observations clearly demonstrated the importance 
of refrigeration in the preservation of stored blood, a recent publication questioned its necessity and claimed that certain preservatives were capable of maintaining erythrocyte viability at room temperature (46). Large amounts of unrefrigerated whole blood were being sent to the European Theatre of Operations in 1944, and since poor preservation of this blood might render it potentially dangerous to recipients the question of refrigeration was reinvestigated.

In the first series of observations, donor blood was drawn directly into Alsever's solution (solution No. 4$)$ at room temperature $\left(25^{\circ}\right.$ C. $)$ and allowed to remain at room temperature until transfused. As illustrated in Figure 7 the post-transfusion survival of these erythrocytes was extremely poor. After 2 days' storage only 65 per cent of erythrocytes survived 24 hours in the recipient's circulation, and after 4 days, only 25 per cent of the cells survived 24 hours.

When blood was taken into chilled ACD, stored at $4^{\circ} \mathrm{C}$. for 3.5 days, and then at room temperature $\left(25^{\circ}\right.$ C. $)$ until transfusion, erythrocyte survival was extremely poor, and after 9 days' storage, none of the labeled cells survived (Figure 7).

The adverse effect of warm temperature was not overcome by returning the blood to refrigeration after it had been exposed for relatively brief pe- riods of time to room temperature. Blood drawn into chilled Alsever's solution, refrigerated at $4^{\circ} \mathrm{C}$. for 2 days, exposed to room temperature $\left(25^{\circ} \mathrm{C}\right.$.) for 24 hours, and then returned to $4^{\circ} \mathrm{C}$., showed considerable decrease in post-transfusion survival (Figure 7).

These studies emphasize the necessity for constant refrigeration of whole blood and of erythrocytes during storage and reconfirm the original observations of Rous and Turner.

\section{Practical application of acid citrate-dextrose solutions}

The acid citrate-dextrose solution of Loutit and Mollison (solution No. 5) and the small volume ACD (solution No. 15) were given extensive practical trials in the blood bank of the Massachusetts Memorial Hospitals. From September, 1944 until January, 1946 the ACD of Loutit and Mollison (solution No. 5) was used for all routine bleedings in the blood bank. During this period 2,576 bloods were taken into this solution, 1,926 transfusions were given, and 217 pints of pooled, frozen plasma were prepared.

The maximum period of storage of this blood was 21 days although most bloods were transfused within the first 10 days after they were drawn. The therapeutic responses to these transfusions

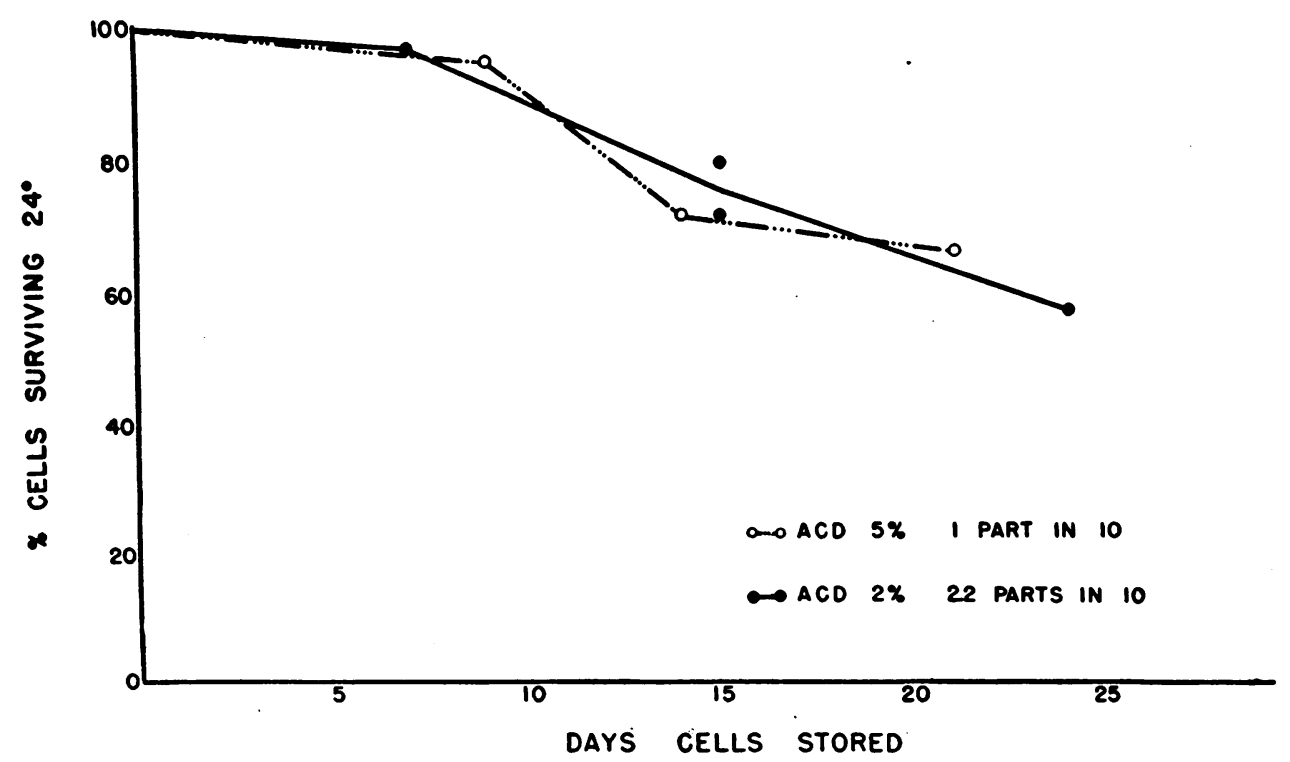

Fig. 6. The Effect of Variation in the Volume of Preservative on the Post-transfusion Surwival of Erythrocytes Separated from Plasma 


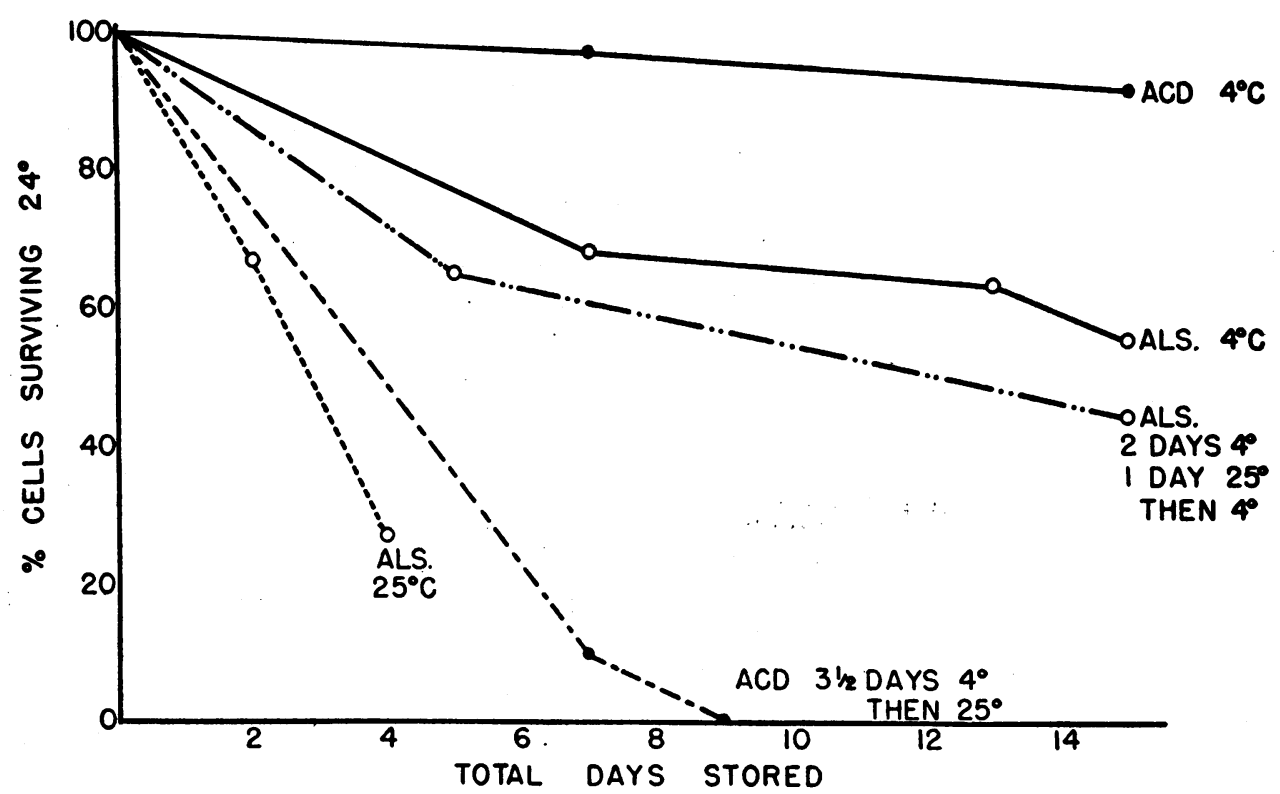

Fig. 7. The Effect of Variation in Storage Temperature on the Post-transfusion Survival of Erythrocytes of Whole Blood

were completely satisfactory, and the incidence of reactions was not higher than that usually prevailing in this blood bank.

The concentration of the citrate ion in the supernatant plasma of the ACD blood mixture is approximately 24 millimolars - a value approximately double the concentration needed to prevent coagulation (47). In spite of this fact, however, there is a tendency to clot formation in blood drawn into this solution unless the blood and anticoagulant are thoroughly mixed during the process of venesection. If this precaution is observed, the incidence of clot formation is no higher than with other preservative fluids, and in our experience has presented no serious difficulty.

From January, 1946 to February, 1947 the 50 ml. of 5 per cent ACD solution (solution No. 15) was used for routine bleedings; 2,522 bloods were drawn into this solution, 2,002 transfusions were dispensed, and 181 pints of frozen plasma were prepared. This preservative was in every respect as satisfactory as the larger volume $\mathrm{ACD}$ preservative.

Packed red blood cells separated,from their plasma were routinely prepared from bloods drawn into each solution as described for solutions No. 14 and 15 . They have proven eminently satisfactory therapeutically, and their use in transfusions for the correction of anemia is steadily increasing.

\section{COM MENT}

Loss of viability of stored erythrocytes proceeds at a very constant rate in blood stored in any given preservative, suggesting that the degenerative process may be one of aging and similar to the process normally going on in the body. The steadiness of the rate of senescence is well illustrated in Figures 4, 5, and 7 in which it appears that the decrease in viable erythrocytes is a straight line function of time. It is possible to calculate the approximate rate of senescence per day for blood stored in different preservatives and such rates are tabulated in Table IV. The rate is high in poor preservatives and at room temperature, and low in good preservatives and in the cold. In all preservatives studied it is higher than the 0.83 to 1.0 per cent per day rate of degeneration of erythrocytes in the body.

Following injection into a recipient, most of the non-viable erythrocytes are removed from the circulation very rapidly-usually within an hour or two. A smaller number are removed at a less rapid rate during the next 10 to 20 hours (Figures 1 and 2 ). The cells which are removed rapidly 
TABLE IV

Maximum allowable duration of storage of blood and separated erythrocytes in various preservatives

\begin{tabular}{|c|c|c|c|}
\hline \multicolumn{2}{|r|}{ Preservative } & \multirow{2}{*}{$\begin{array}{c}\text { Maximum } \\
\text { duration } \\
\text { storage } \\
\text { permitting } \\
70 \text { per cent } \\
\text { post- } \\
\text { transfusion } \\
\text { survival }\end{array}$} & \multirow{2}{*}{$\begin{array}{l}\text { Approximate } \\
\text { rate of } \\
\text { degeneration } \\
\text { of r.b.c. } \\
\text { in vitro }\end{array}$} \\
\hline $\begin{array}{l}\text { Solu- } \\
\text { tion } \\
\text { no. }\end{array}$ & Name & & \\
\hline & Whole blood & days & $\begin{array}{l}\text { per cent } \\
\text { per day }\end{array}$ \\
\hline $\begin{array}{l}2 \\
6 \\
5\end{array}$ & $\begin{array}{l}\text { Denstedt's } \\
\text { Acid citrate-dextrose } \\
\text { Acid citrate-dextrose }\end{array}$ & $\begin{array}{l}24 \\
23\end{array}$ & $\begin{array}{l}1.4 \\
1.4\end{array}$ \\
\hline $\begin{array}{l}4 \\
1\end{array}$ & $\begin{array}{l}\text { (Loutit and Mollison) } \\
\text { Alsever's } \\
\text { Trisodium citrate }\end{array}$ & $\begin{array}{r}22 \\
7 \\
5\end{array}$ & $\begin{array}{l}1.4 \\
3.0 \\
7.0\end{array}$ \\
\hline 14 & $\begin{array}{l}\text { Separated cells } \\
\text { R.b.c. from blood in ACD } \\
\text { of Loutit and Mollison }\end{array}$ & 20 & 1.5 \\
\hline 16 & $\begin{array}{l}\text { R.b.c. from blood in } 5 \text { per } \\
\text { cent acid citrate. Dex- } \\
\text { trose added later }\end{array}$ & 24 & 1.3 \\
\hline 15 & $\begin{array}{l}\text { R.b.c. from blood in } 5 \text { per } \\
\text { cent ACD }\end{array}$ & 20 & 1.5 \\
\hline 7 & $\begin{array}{l}\text { R.b.c. suspended in albu- } \\
\text { min solution }\end{array}$ & 22 & 1.4 \\
\hline 13 & $\begin{array}{l}\text { R.b.c. suspended in RPA } \\
\text { fluid }\end{array}$ & 18 & 1.7 \\
\hline $\begin{array}{r}12 \\
8\end{array}$ & $\begin{array}{l}\text { Maltose-dextrose } \\
\text { Corn syrup }\end{array}$ & $\begin{array}{l}15 \\
10\end{array}$ & $\begin{array}{l}2.0 \\
3.0\end{array}$ \\
\hline
\end{tabular}

probably are dead prior to injection; those removed at the slower rate probably have been damaged during storage and become non-viable after injection.

The longer a blood has been stored and the more non-viable erythrocytes there are-the more rapid is the rate at which the non-viable cells are removed. This may be accounted for by progressive changes in the stored erythrocytes after they have become non-viable-a "postmortem degeneration," so to speak. If these changes are extensive enough they may result in actual disintegration of the erythrocytes and be reflected by gross hemolysis in the stored blood. As described in a subsequent paper, however, extensive degenerative changes may occur in erythrocytes stored in some preservatives, without gross hemolysis or other evidence of cell disintegration.

Our studies have been directed primarily at a critical evaluation of the effectiveness of certain selected preservatives, rather than at a general survey of the properties of preservative fluids. However, there are certain important features of blood preservatives which have become apparent in our studies, and these will be commented on briefly. The presence of dextrose in a preservative solution is essential for maintenance of erythrocyte viability. Its actual concentration does not appear to be critical within the range of 0.5 to 2.0 per cent. The initial reaction of the preservative-blood mixture is important and should be between $\mathrm{pH}$ 6.8 and 7.0. Certain autolytic or destructive processes probably are retarded at this $\mathrm{pH}$. The degree of dilution of the blood with preservative fluid is not of great importance. The survival of erythrocytes stored in a cell mass with a hematocrit of 88 per cent is little different from the survival of cells stored in a whole blood-preservative mixture with a hematocrit of 30 per cent. The presence of plasma in the preserving medium is not essential for good erythrocyte preservation, and there is some evidence that its removal may improve preservation. The importance of constant refrigeration has already been emphasized. The addition of vitamins, amino acids, and other accessory substances is not essential and does not improve erythrocyte preservation.

In adopting the arbitrary value of 70 per cent post-transfusion survival as a minimum requirement for satisfactory transfusion properties, we do not wish to imply that blood providing cells of this viability is as satisfactory as blood in which a greater percentage or all of the cells are viable. Although blood stored for 3 weeks and providing erythrocytes of 70 per cent viability may be "satisfactory" for transfusion under emergency circumstances, it is not so good as fresh blood or blood stored for a shorter period of time. During the war when large quantities of blood had to be shipped literally to the ends of the earth it was occasionally necessary to use blood stored for 3 weeks, and such blood saved the lives of thousands of American troops. In civilian practice and in most hospital blood banks there is no necessity for using blood stored this long.

From a practical standpoint, however, transfusion of blood stored in ACD, or one of the modifications of $A C D$, for 7 to 10 days may be considered as satisfactory as fresh blood for the relief of anemia.

\section{SUM MARY}

(1) The effectiveness of 16 solutions and of various techniques in the preservation of whole 
blood, and of erythrocytes separated from plasma have been evaluated with the radioactively tagged erythrocyte technique.

(2) The most effective preservative and the simplest to prepare was an acid citrate-dextrose solution.

(3) Whole blood drawn into this solution maintained satisfactory transfusion properties during a storage period of 21 days.

(4) Erythrocytes separated from blood drawn into this acid citrate-dextrose solution and stored without addition of diluent also maintained satisfactory transfusion properties during a storage period of 21 days.

(5) This acid citrate-dextrose solution proved to be very satisfactory in routine hospital blood bank use.

(6) Studies of the influence of temperature on the viability of stored erythrocytes emphasized the necessity for constant refrigeration of blood during the entire period of storage.

\section{ACKNOWLEDGMENT}

We wish to acknowledge gratefully the willing cooperation of the medical students of the Boston University School of Medicine and the Professional Staff of the Massachusetts Memorial Hospitals who served as subjects for the majority of these studies.

\section{BIBLIOGRAPHY}

1. Emerson, C. P., Jr., and Ebert, R. V., A study of shock in battle casualties, measurements of the blood volume changes occurring in response to therapy. Ann. Surg., 1945, 122, 745.

2. Ross, J. F., and Chapin, M. A., Effect of storage of citrated blood on the survival of transfused erythrocytes. J. A. M. A., 1943, 123, 827.

3. Rous, P., and Turner, J. R., The preservation of living red blood cells in vitro. J. Exper. Med., 1916, 23, 219.

4. Robertson, O. H., Transfusion with preserved red blood cells. Brit. M. J., 1918, 1, 691.

5. De Gowin, E. L., Harris, J. E., and Plass, E. D., Studies on preserved human blood. I. Various factors influencing hemolysis. J. A. M. A., 1940, 114, 850.

6. De Gowin, E. L., Harris, J. E., and Plass, E. D., Studies on preserved human blood. II. Diffusion of potassium from the erythrocytes during storage. J. A. M. A., 1940, 114, 855.

7. Belakhouski, S. D., Ginzburg, F. G., Palichina, A., Rzechina, S. V., and Farberova, R., Preservation of blood intended for blood transfusion. Sovr. probl. gematal., 1932, 3-4, 16.
8. Yudin, S. S., Transfusion of stored cadaver blood; practical considerations: the first thousand cases. Lancet, 1937, 2, 361.

9. Jorda, F. D., The Barcelona blood transfusion service. Lancet, 1939, 1, 773.

10. Fantus, B., The therapy of Cook County Hospital: blood preservation. J. A. M. A., 1937, 109, 128.

11. Alsever, J. B., and Ainslie, R. B., A new method for the preparation of dilute blood plasma and the operation of a complete transfusion service. New York State J. Med., 1941, 41, 126.

12. Mollison, P. L., and Young, I. M., On the survival of the transfused erythrocytes of stored blood. Quart. J. Exper. Physiol., 1941, 30, 313.

13. Mollison, P. L., and Young, I. M., In vivo survival in the human subject of transfused erythrocytes after storage in various preservative solutions. Quart. J. Exper. Physiol., 1942, 31, 359.

14. Loutit, J. F., and Mollison, P. L., Advantages of a disodium citrate-glucose mixture as a blood preservative. Brit. M. J., 1943, 2, 744.

15. Loutit, J. F., Mollison, P. L., and Young, I. M., Citric acid-sodium citrate-glucose mixtures for blood storage. Quart. J. Exper. Physiol., 1943, 32, 183.

16. Loutit, J. F., Factors influencing the preservation of stored red cells. J. Path. and Bact., 1945, 57, 325.

17. Denstedt, O. F., Osborne, D. E., Stansfield, H., and Rochlin, I., The survival of preserved erythrocytes after transfusion. Canad. M. A. J., 1943, 48, 477.

18. Denstedt, O. F., Osborne, D. E., Stansfield, H., and Rochlin, I., The survival of preserved red cells after transfusion. Anesthesiology, 1944, 5, 237.

19. Ashby, W., The determination of length of life of transfused blood corpuscles in man. J. Exper. Med., 1919, 29, 267.

20. Wiener, A. S., Longevity of erythrocytes. J. A. M. A., 1934, 102, 1779.

21. Mollison, P. L., and Young, I. M., Failure of in vitro tests as a guide to the value of stored blood. Brit. M. J., 1941, 2, 797.

22. Maizels, M., Phosphate, base and hemolysis in stored blood. Quart. J. Exper. Physiol., 1943, 32, 143.

23. Hahn, P. F., Bale, W. F., Ross, J. F., Hettig, R. A., and Whipple, G. H., Radio-iron in plasma does not exchange with hemoglobin iron in red cells. Science, 1940, 92, 131.

24. Ross, J. F., and Chapin, M. A., The electrolytic separation of radioactive iron from the blood. Rev. Scient. Instruments, 1942, 13, 77.

25. Peacock, W. C., Evans, R. D., Irvine, J. W., Jr., Good, W. M,. Kip, A. F., Weiss, S., and Gibson, J. G., The use of two radioactive isotopes of iron in tracer studies of erythrocytes. J. Clin. Invest., 1946, 25, 605.

26. Ebert, R. V., and Emerson, C. P., Jr., A clinical study of transfusion reactions: the hemolytic effect of group-O blood and pooled plasma containing incompatible isoagglutinins. J. Clin. Invest. 1946, 25, 627. 
27. Heller, V. G., and Paul, H., Changes in cell volume produced by varying concentrations of different anticoagulants. J. Lab. \& Clin. Med., 1934, 19, 777.

28. Chapin, M. A., and Ross, J. F., The determination of the true cell volume by dye dilution, by protein dilution, and with radioactive iron. The error of the centrifuge hematocrit. Am. J. Physiol., 1942, $137,447$.

29. Hahn, P. F., Ross, J. F., Bale, W. F., Balfour, W. M., and Whipple, G. H., Red cell and plasma volumes (circulating and total) as determined by radio iron and by dye. J. Exper. Med., 1942, 75, 221.

30. Gibson, J. G., 2nd, Weiss, S., Evans, R. D., Peacock, W. C., Irvine, J. W., Jr., Good, W. M., and Kip, A. F., The measurement of the circulating red cell volume by means of two radioactive isotopes of iron. J. Clin. Invest., 1946, 25, 616.

31. Ross, J. F., Chapin, M. A., Sammons, M. E., and Paegel, B. L., The total red blood cell volume of normal human subjects determined with erythrocytes labeled with radioactive iron. Blood. (In press.)

32. Gibson, J. G., 2nd, and Evelyn, K. A., Clinical studies of the blood volume. IV. Adaptation of the method to the photoelectric microcolorimeter. J. Clin. Invest., 1938, 17, 153.

33. Price, P. B., and Longmire, W. P., The use of T1824 in plasma volume determinations. Bull. Johns Hopkins Hosp., 1942, 71, 51.

34. Noble, R. P., and Gregersen, M. I., Blood volume in clinical shock. I. Mixing time and disappearance rate of T-1824 in normal subjects and in patients in shock; determination of plasma volume in man from 10-minute sample. J. Clin. Invest., 1946, 25, 158.

35. Ross, J. F., Unpublished observations.

36. Thalhimer, W., and Taylor, E. S., Transfusion of centrifuged human type $O$ cells resuspended and stọred in 10 per cent corn syrup. J. A. M. A., $1945,127,1096$.
37. Ball, E. G., Anfinsen, C. B., Geiman, Q. M., McKee, R. W., and Ormsbee, R. A., In vitro growth and multiplication of the malarial parasite, Plasmodium knowlesi. Science, 1945, 101, 542.

38. Evelyn, K. A., A stabilized photoelectric colorimeter with light filters. J. Biol. Chem., 1936, 115, 63.

39. Wintrobe, M. M., Size and hemoglobin content of erythrocytes; methods of determination and clinical application. J. Lab. \& Clin. Med., 1932, 17, 899.

40. Flink, E. B., and Watson, C. J., Method for quantitative determination of hemoglobin and related heme pigments in feces, urine, and blood plasma. J. Biol. Chem., 1942, 146, 171.

41. Malloy H. T., and Evelyn, K. A., The determination of bilirubin with the photoelectric colorimeter. J. Biol. Chem., 1937, 119, 481.

42. Folin, O., and Malmros, H., Improved form of Folin's micro method for blood sugar determination. J. Biol. Chem., 1929, 83, 115.

43. Dacie, J. V., and Vaughan, J. M., Fragility of red blood cells : its measurement and significance. $J$. Path. \& Bact., 1938, 46, 341.

44. Shen, S. C., Ham, T. H., and Fleming, E. M., Studies on the destruction of red blood cells. III. Mechanisms and complications of hemoglobinuria in patients with thermal burns. Spherocytosis and increased osmotic fragility of red blood cells. New England J. Med., 1943, 229, 701.

45. Furchgott, R. F., and Ponder, E., Disk-sphere transformation in mammalian red cells. II. The nature of the anti-sphering factor. J. Exper. Biol., 1940, $17,117$.

46. Kendrick, D. B., Jr., Elliott, J., Reichel, J., Jr., and Vaubel, E. K., Supply of preserved blood to European theatre of operations, a preliminary report. Bull. U. S. Army M. Dept. (No. 84), 1945, 3, 66.

47. Maizels, M., Observations on stored blood, report B. T. 30, to the Medical Research Council, Blood Transfusion Research Committee, January, 1943. 